\title{
Anger over French synchrotron decision
}

[PARIS] French scientists are challenging a government decision not to earmark any funds to build a new FF1.4 billion (US\$244 million), $2.15-\mathrm{GeV}$ synchrotron radiation facility, Soleil, in the 1999 science budget.

Many researchers had hoped that construction would be given the go-ahead at an interministerial committee meeting in January. But Claude Allègre, the minister of research, has described the facility in a parliamentary debate as costly and only of interest to "about 40 researchers". Referring to foreign access to the facility, Allègre said that building the machine would be a financial subsidy "to British research".

The minister also claimed that much of the impetus for construction originated in rivalry between the regions seeking to host Soleil. Finally, Allègre claimed that French scientists would not suffer because they could continue to use other existing thirdgeneration synchrotron sources (see Nature $395,831 ; 1998)$,

Several directors of synchrotron facilities, however, have signed a joint letter saying that it is impossible for them to accommodate "a scientific community as large and diversified as the French". Signatories of the letter include Nils Märtensson of MAX-lab at Lund in Sweden, Herbert Moser of ANKA at Karlsruhe in Germany and Jochen Schneider of HASYLAB in Hamburg.

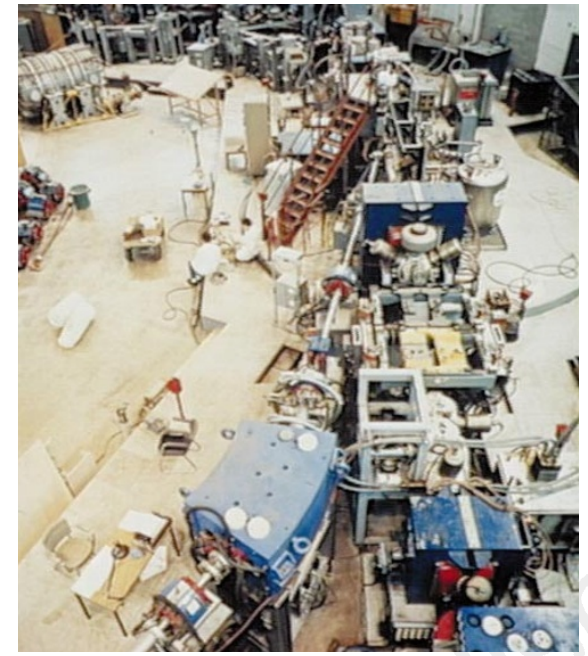

The LURE source at Orsay: already heavily used.

Yves Petroff, director-general of the European Synchrotron Radiation Facility at Grenoble, says he does not know "where Allègre got his figures from, but they are so ridiculous it is not even worth replying". The figure of 40 refers not to the number of researchers but to the number of beam lines that Soleil will offer, says Petroff, adding that more than 2,000 researchers use the secondgeneration light source LURE at Orsay.

The candidate host regions have asked for the decision on whether to build Soleil to be independent of that of where to site it. Arguing that "the decision to construct Soleil is a top priority", they have also agreed that the host region will contribute to funding the light source and the planned beam lines during the initial programme, while the other regions will pay to build additional beam lines specific to the activities of their researchers. Allègre has been aware of this agreement for several months, as a letter signed by the six main scientific backers of the project was sent to him in July. No reply has yet been received.

François Wuilleumier, chair of the committee 'Soleil for the Ile-de-France', points out that this arrangement is already working for two beam lines at LURE. Similar agreements exist with Spain and Switzerland.

Several researchers at the Centre National de la Recherche Scientifique (CNRS) say that Allègre's desire to encourage interdisciplinary research and create a centre for genome research (Génopole) is inconsistent with his refusal to build a machine that is essential for the future of genomic research.

Without Soleil, say Christian Le Brun and Jean-Pierre Couture, directors of research at the CNRS, "France will become an underdeveloped country" at a time when the major European nations are equipping themselves, as in the United Kingdom, or have already done so, as in Germany.

Eric Glover

\section{Reprieve on the cards for reform to Italian research council}

[MUNICH] Italy's new government, which came to power in October, is expected to modify proposals for the reform of the National Research Council (CNR), which is responsible for more than 300 research institutes and centres.

As a result, the council could maintain part of its grant-giving role - this would have been removed under the earlier version of the reforms - and keep its scientific advisory committees under its own wing.

The earlier reforms, intended to increase the efficiency with which Italian science is organized, were included in a decree which failed to receive complete approval before the collapse of the government of former prime minister Romano Prodi. But the government did approve a measure to dissolve the current organization of the CNR at the end of this year.

Decrees covering organizational reforms to the Italian Space Agency and the energy and environment agency have been approved by parliament in the past few weeks. But the CNR decree was held back for review by the new research minister, Ortensio Zecchino (see Nature 395, 827; 1998).

Zecchino, a member of the Catholic PPI party (Partito populare italiano), has close political links with Lucio Bianco, the president of CNR. Bianco had felt that some aspects of the original decree weakened the influence and autonomy of the CNR, partly because members of its committees would be appointed by the research ministry (see Nature 395, 203; 1998).

Bianco put forward a series of modifications to the decree which were presented to parliament last week. First, he suggested that the planned disciplineorientated consigli nazionale (scientific advisory committees), which will serve the new government-level committee of experts for scientific policy, should be within the $\mathrm{CNR}$, rather than in the research ministry as planned. He suggested that they should also be responsible for advising the CNR board.

When the current CNR organization is dissolved at the end of this year, the research council's 15 scientific advisory committees, which have been responsible for allocating research funds and advising the government on scientific issues, will disappear.

By tapping directly into the new government scientific advisory structure, Bianco hopes to restore some of the political influence the CNR has traditionally enjoyed. But some scientists are worried that if the CNR uses the consigli nazionali as its advisory committees, rather than creating its own, it could mean a continuation of the influence of powerful university professors, known as baroni, over CNR policy.

Bianco says "there will be no return to the power of the baroni" because the committees will be advisory only and will not directly influence the allocation of funds. But many CNR scientists would still prefer their own advisory committees, where they could be represented in greater numbers, even if these did not have the direct ear of the government.

Bianco had been unhappy that the grantgiving role of the research council was to be transferred to other organizations, including the research ministry (see Nature $394,712 ; 1998)$. His second suggestion returns to the CNR the responsibility for allocating Italy's large research grants for politically defined strategic projects, as well as small grants to allow young researchers to test new ideas.

The new decree has now to be approved by the government.

NATURE |VOL 396 | 3 DECEMBER 1998 | www.nature.com 